\title{
Populism and the American Party System: Opportunities and Constraints
}

\author{
Frances E. Lee
}

\begin{abstract}
Does populism threaten American democracy, and if so, what is the nature of that threat? In dialogue with the comparative literature on populism, this article considers the opportunity structure available to populist parties and candidates in the American political system. I argue that compared to most other democracies, the US system offers much less opportunity for organized populist parties but more opportunity for populist candidacies. Today's major parties may also be more vulnerable to populist insurgency than at other points in US history because of (1) changes in communications technology, (2) the unpopularity of mainstream parties and party leaders, and (3) representation gaps created by an increasingly racialized party system. Although no democratic system is immune to deterioration, the US constitutional system impedes authoritarian populism, just as it obstructs party power generally. But the vulnerability of the major parties to populist insurgency poses a threat to liberal democratic norms in the United States, just as it does elsewhere.
\end{abstract}

$\square$ oes populism threaten American democracy, and if so, what is the nature of that threat? This article draws on the extensive comparative research on populism to consider the "political opportunity structure" (Tarrow 1996) for populist parties and candidates in the United States. Scholars of American politics have given limited attention to populism either as a general phenomenon or its impact on US democracy. Most research on the topic has focused on the incidence of populist rhetoric in American politics over time (Bimes and Mulroy 2004; Bonikowski and Gidron 2015; Gerring 1998) or the Populist mobilizations of the 1890s (Sanders 1999).

Frances E. Lee (1D) is Professor of Politics and Public Affairs at Princeton University (frances.lee@princeton.edu). She is editor of the Cambridge Elements Series in American Politics and author of Beyond Ideology: Politics, Principles, and Partisanship in the US Senate (2009) and Insecure Majorities: Congress and the Perpetual Campaign (2016).

Earlier versions of this article were presented at meetings of the American Political Science Association and the Deutsche Vereinigung Für Politikwissenschaf. For their comments, I thank Larry Bartels, Jim Curry, Kirk Hawkins, David Karol, Emery Lee, Neil Lund, Jenny Mansbridge, David Samuels, Eric Schickler, Danielle Thomsen, Rick Valelly, and Kurt Weyland, as well as participants in the American Politics Workshop at the University of Maryland. For research assistance, I am grateful to Katti McNally and SoRelle Wyckoff.
Unlike comparativists, scholars of American politics have not analyzed how the US political system facilitates or checks populist impulses or whether populism has the potential to undermine American democracy.

As this article shows, there is much Americanists can learn from the comparative study of populism. Comparativists have developed a definition of populism that travels well and can be applied to the study of parties and candidates in the United States (Mudde and Kaltwasser 2017). Scholars of comparative politics have amassed a large body of work on the causes and consequences of populism that has clear relevance to conditions in the United States. Most importantly, Americanists can benefit from a closer engagement with the comparative literature that demonstrates that populist parties and leaders in power constitute a risk factor for democratic backsliding. Building on the comparative literature, this article analyzes the ways in which the US system is both vulnerable and resistant to populist-driven democratic erosion. My hope is that the synthesis offered here encourages more crosssubfield dialogue in political science and points to new avenues for research in American politics.

Compared to most other democracies, I argue that the US system offers much less opportunity for organized populist parties but far more opportunity for populist candidacies. Although the US electoral system limits prospects for populist parties, its major parties are far more porous to populist candidacies than the mainstream parties in other democracies. Indeed, the openness of major parties to populist challenge and the pervasiveness of populist rhetoric blur the distinction between populist and mainstream politics in the United States. As Ware (2002, 
119) observes, "Populism is everywhere in American politics, but nowhere in particular."

Today's major US parties may be more vulnerable to populist internal challenge than they were at earlier points, given (1) developments in communications technology, (2) the unpopularity of mainstream parties and party leaders, and (3) representation gaps created by an increasingly racialized party system. In light of these developments, I argue that populist insurgency threatens the inclusive norms of liberal democracy in the United States, just as it does elsewhere. However, the same features of the US system that impede its responsiveness to national popular majorities-federalism, bicameralism, and separate elections for national offices_-also help insulate the United States against a would-be authoritarian leader's centralized control. Populist insurgency may contribute to further polarization, with negative consequences for the performance of American governing institutions. Yet populism likely poses greater risks to liberal values than to formal democratic institutions and practices.

This article is organized as follows. In the first section I define populism and discuss why scholars of comparative politics see it as a threat to democracy. The next section synthesizes work documenting the receptivity of the American public to populist appeals. The third section examines the effects of rules governing party nominations and elections on the opportunities for populist parties and candidates. The fourth section goes beyond institutions to examine key factors that may have enhanced the prospects for populist insurgency in American politics. The fifth section considers the prospects for populist authoritarianism in the United States. I conclude by arguing that twenty-first-century populism seems likelier to yield a more illiberal, racially divisive party politics in the United States than an entrenched authoritarian regime.

\section{Populism and the Threat to Democracy}

The transnational rise of populism has featured prominently in global politics since the early 1990s (Judis 2016; Moffitt 2016). A worldwide "populist zeitgeist" (Mudde 2004) was evident long before the 2008 financial crisis, Brexit, the Syrian civil war and the surge of migration to Europe, or the US presidential election of Donald J. Trump. Populism's global strength has generated hundreds of recent books and articles, although before the 2016 elections most such studies dealt with countries other than the United States. ${ }^{1}$

Scholars of comparative politics generally view the rise of populist parties and leaders as a "peril" (Müller 2016) or "challenge" (Mény and Surel 2002), because populism "always stands in tension with democracy" (Weyland 2013). Although populist leaders claim the mantle of popular sovereignty, once in power they tend to degrade democracy by weakening civil liberties, the rule of law, and the fairness of electoral processes. Recent cases of democratic erosion under populist leaders include Turkey under Recep Tayyip Erdoğan, Ecuador under Rafael Correa, Venezuela under Hugo Chavez and Nicolás Maduro, Poland under the Law and Justice Party, and Hungary under Viktor Orban.

Although the concept may appear amorphous, a clear definition of populism has gained wide (albeit not universal) acceptance among scholars. Mudde and Kaltwasser $(2017,6)$ write,

"Populism is a thin-centered ideology that considers society to be ultimately separated into two homogeneous and antagonistic camps, 'the pure people' versus 'the corrupt elite,' and which argues that politics should be an expression of the general will of the people." Populism is "thin-centered" in that it is "limited in ideational ambitions and scope" (Freeden 1998, 750). It encompasses only a few, very simple concepts that can be flexibly combined with other, more complex political ideas and ideologies, yielding populisms that range across the political spectrum from extreme left to extreme right (Hawkins and Kaltwasser 2018). There are even neoliberal populisms of the center that champion austerity and market-oriented reform (Roberts 1995).

Whether of the left, right, or center, populism is a moralistic discourse that turns on a Manichean dichotomy between a corrupt governing elite and a virtuous, homogeneous people (Hawkins 2009). The emphasis on the homogeneity of the people makes populism fundamentally anti-pluralist (Müller 2016). Populism's harsh rhetoric around the corrupt elite scorns the legitimacy of political opposition: no institutional procedures or constraints should stand in the way of the people's will. Populist conceptions of the general will thus typically envision "majority rule without minority rights" (Grzymala-Busse 2017a, S1).

Populism's intolerant attitude toward opposition tends toward authoritarianism. Although populist parties, movements, and leaders may give voice to ignored concerns and incorporate excluded societal groups (Kaltwasser 2014), most comparativists view populism as fundamentally incompatible with liberal democracy (Rummens 2017). Populists in power tend to empower executives, weaken checks and balances, restrict civil liberties, and manipulate electoral institutions to cement their power against challenge (Hawkins and Littvay 2019; Houle and Kenny 2018; Huber and Schimpf 2016; Kenny 2017; Ruth 2018).

These antidemocratic effects hold regardless of ideological orientation. In cross-national studies, populists of the left, right, and center in power are all on average equally associated with declines in free and fair elections, civil liberties, and constraints on executives (Hawkins and Littvay 2019; Ruth-Lovell, Doyle, and Hawkins 2019). Kenny (2019) finds that left-leaning populist governments 
tend to exercise an even more negative effect on press freedom. Populists in government do not always succeed in undermining liberal democracy (Weyland and Madrid 2019), but they constitute a risk factor for democratic erosion.

Although populism's adverse consequences for liberal democracy are well documented in the comparative literature, scholars have generally not considered it a threat to US democratic institutions. At least since the Civil War, few students of American politics have expressed any anxiety about the durability of American democratic institutions (Kammen 1987). So, where the comparative literature routinely describes populism as a "pathology" (Taggart 2002, 62) or a "degraded form" (Müller 2016, 6) of democracy, in the American context it is usually presented in neutral (Gerring 1998; Kazin 1995) or even positive (Dzur 2010; Grattan 2016) terms. Even Hofstadter $(1955,18)$ - who criticizes the nativism, antisemitism, conspiratorial thinking, and other illiberal impulses of late nineteenth- and early twentieth-century Populists-assesses populism as promoting needed reforms and yielding "substantial net value" for American democracy. Rather than a danger to democratic institutions, populism in the United States is instead seen as a rhetorical tradition operating within the confines of normal partisan (Gerring 1998) or presidential politics (Azari 2017; Bimes and Mulroy 2004; Bonikowski and Gidron 2015).

\section{Americans' Receptivity to Populist Rhetoric}

The United States can lay some claim to having invented populism. President Andrew Jackson's 1830s rhetoric pitting the "common man" against the "corrupt aristocracy" contains the hallmarks of populist discourse, as usually defined. The first broad populist mobilizations occurred in the United States with the People's Party of the 1890s.

Like populism cross-nationally, US populism has manifested in right-wing, left-wing, and centrist forms (Lowndes 2017). Defining populism expansively, Kazin (1995) tracks it through the original Populists, labor leader Samuel Gompers, the evangelical protestant Prohibitionists, the Catholic Father Coughlin, Sen. Joseph McCarthy, and the New Right of Alabama governor George Wallace and his successors. Gerring's (1998) study of party platforms, campaign speeches, and other electioneering documents finds that populist rhetoric was a dominant discourse for the Democratic Party between 1896 and 1948 and for the Republican Party since 1928. In recent decades, it has flourished more on the right than the left (Bimes and Mulroy 2004; Gerring 1998, 233-53; Kazin 1995, 245-66), although in the 2016 Democratic presidential primaries Sen. Bernie Sanders inveighed against a "rigged economy" that privileges the $1 \%$ over the $99 \%$.
As history makes clear, populist appeals find a receptive audience in the United States. Long before the antiestablishment fervor of the 2016 elections, Hibbing and Theiss-Morse (1995) documented that many Americans embrace notions of an organic and wholesome people in contradistinction to a corrupt, out-of-touch political elite. Focus group participants in their studies repeatedly fell into talking about the wishes of the American people as if there were a single public mind in accord with populism's anti-pluralist rhetoric. Large majorities express disdain of a "Washington system" of special interests, little understanding of the sources of disagreement in Congress, and impatience with debate and deliberation. Disgusted with the contentiousness of real-world democracy, "surprising percentages of people respond favorably to the mention of decision-making structures that are not democratic," such as turning government over to "successful business-people" (Hibbing and Theiss-Morse 2002, 138).

Americans' "affinity for populist discourse seems to be quite high," particularly among those with lower levels of education and among conservatives (Hawkins, Riding, and Mudde 2012, 12). Americans tend to agree with populist sentiments such as "politics usually boils down to a struggle between the people and the powerful" (Oliver and Rahn 2016, 197) and "the power of a few special interests prevents our country from making progress" (Hawkins, Riding, and Mudde 2012, 29).

American public opinion cannot be relied on as a bulwark of liberal rights capable of resisting populism's tendencies toward authoritarianism and anti-pluralism. The values undergirding liberal democracy are fragile at the grassroots (McClosky 1964). The American mass electorate demonstrates only weak understanding of and adherence to basic democratic values (Prothro and Grigg 1960). Americans are often unwilling to apply the abstract civil libertarian principles they espouse to specific unpopular groups (Sullivan, Piereson, and Marcus 1982). Authoritarian (Hetherington and Weiler 2009) and ethnocentric (Kinder and Kam 2009) beliefs are major drivers of public opinion.

American attitudes are hardly unique in providing a favorable terrain for populist appeals. Bartels (2017), for example, finds a robust, albeit static, "reservoir" of populist sentiment across western Europe. "Populist attitudes are intrinsic to democracy," conclude Hawkins, Riding, and Mudde (2012, 24). Because populist ideas resonate with the mass public in most democracies, what matters more is the opportunity structure in which those populist appeals are made.

\section{Electoral Rules and US Populism}

The US electoral system has long been unfavorable to insurgent or third parties, including populist parties. At the same time, however, the American system of nominations subjects the major parties to radically open 
internal competition through primary elections. The combined result of these electoral rules is that populists win more favorable outcomes in intraparty competition than in interparty competition.

\section{Electoral Rules}

Although scholars disagree on the importance of electoral systems for populist party success, studies show that proportional representation-particularly when there are low electoral thresholds (Ignazi 2003; Norris 2005) and more seats are allocated via upper-tier correction (Golder 2003; Veuglelers and Magnan 2005) —increases the likelihood that populist parties will win legislative seats. As one of the few holdouts among advanced democracies, the United States has thoroughly resisted any move toward proportional representation. With first-past-the-post electoral rules nearly universal in the United States, barriers to third-party entry are high. A party or candidate needs to be able to credibly contend for an outright plurality or risks losing strategic support because of a perception of "wasted" votes and campaign resources (Duverger 1986; Tamas 2018, 146-63).

The United States is one of the only countries in the world with no uniform national ballot access law, and the regulations imposed by states can be onerous for third parties (Rosenstone, Behr, and Lazarus 1984). A new party seeking presidential ballot access must navigate the complexity of differing requirements and deadlines across 50 states and the District of Columbia. These barriers restrict opportunities for third parties, populist or otherwise.

The lack of majority runoff elections may also limit the opportunities for populist and other third parties in the United States. ${ }^{2}$ Where runoffs are possible, multiple parties and long-shot candidates have greater incentive to run and may be able to draw sufficient support to move to the second round (Shugart and Carey 1992). The majority runoff format, for example, was a key factor in the sudden, sweeping success of outsider populist Alberto Fujimori in the 1990 Peruvian election (Schmidt 1996). With many candidates running in the first round, the obscure Fujimori only needed to come in second to compete in a twocandidate contest in the next round.

Despite the multiple disincentives for third parties, US electoral rules have not fully suppressed populist parties (Tamas 2018). Indeed, since the Civil War, nearly all of the most successful third-party presidential bids were to a great extent populist in character, including the Populist Party itself in 1892, Theodore Roosevelt's Bull Moose Party in 1912, Robert "Fighting Bob" La Follette's Progressives in 1924, Ross Perot's centrist campaign in 1992 and his Reform Party in 1996, and George Wallace's American Independent Party in 1968. In light of the obstacles third parties face, these candidates' electoral performance-Perot got nearly $20 \%$ of the national vote in 1992! - testifies to the resonance of populist appeals in the United States. But in the end all these candidates fared poorly in terms of Electoral College votes.

\section{Party Primaries}

Populist parties are fringe players in US politics, but populist challengers can and do compete successfully in intraparty politics. Although the trend cross-nationally has been toward increased use of primaries, caucuses, and other more "democratic" means of allocating nominations (Rosenbluth and Shapiro 2018), the United States has long been and remains an outlier in terms of the radical openness of its party nomination processes (Sandri, Seddone, and Venturino 2015).

The post- 1968 party reforms of the presidential nomination process opened up the major parties to almost routine internal populist challenges. In 1972, George Wallace abandoned third-party politics to compete in the Democratic presidential primaries. His populist campaign against the corrupt elite-which in his formulation included "government bureaucrats," "pointy-head college professors," and "unelected judges" - gained traction outside the South with disaffected working-class voters until his campaign was cut short by a nearly successful assassination attempt. Since 1972, most populist outsider presidential candidates have followed Wallace's lead in turning from third parties to major party primaries.

Populist candidates have been a recurring feature of presidential nomination contests since the 1970s. Dark horse Georgia governor Jimmy Carter won the Democratic nomination for president in 1976 with an outsider's campaign resonant with populist themes. Rev. Jesse Jackson's 1988 campaign for the Democratic nomination channeled discontent with economic elites into a "gospel populism" (Hertzke 1993). California governor Jerry Brown sought the Democratic nomination in 1992 vowing to "take back America from the confederacy of corruption, careerism, and campaign consulting in Washington." ${ }^{3}$ Pat Buchanan ran spirited campaigns for the Republican presidential nomination in 1992 and 1996, proclaiming to the party establishment that the "peasants are coming with pitchforks." Arkansas governor Mike Huckabee ran for the Republican nomination in 2008 "regularly taking digs at Wall Street, free trade, and 'the rich." 4 Sen. John Edwards (D-NC) styled himself as a populist in the 2008 contest for the Democratic presidential nomination, railing against the "moneyed interests" that have a "stranglehold on our democracy."

In most (but by no means all) cases, the party establishment succeeded in beating back populist insurgents, when key groups in the party coalition coalesced around a mainstream favorite and starved competitors for financial support in the "invisible primary" (Cohen et al. 2008). But in a system where party nominations are open 
to all comers and outcomes are decided in primaries and caucuses, the potential for a successful populist challenge is nothing new. Trump's nomination and election simply realize what had been a latent possibility since the post1968 party reforms (Cohen et al. 2016).

Similarly, populist aspirants to a seat in Congress are likely to find it easier to win a major party primary than to win as a third-party candidate. Ballot access is much less of an obstacle for third parties seeking House and Senate seats than the presidency, because a new party only needs to meet whatever petition or other requirements are imposed in one state (rather than 50). ${ }^{5}$ Populists have won congressional seats at various points in history as third-party candidates (Clanton 1984; Tamas and Hindman 2014). But third parties do not have automatic access to state ballots. Meanwhile, unlike for the presidency - where binding primaries only became the norm after 1968 - primaries have been used to decide most party nominations for House and Senate seats since the progressive reforms of the early twentieth century. Thus populists have long had an open path to capture major party nominations for Congress.

There is a dearth of research on the number of candidates who have won party nominations and seats in Congress on the strength of populist appeals. However, the path by which populists get to Congress only occasionally takes the form of hard-fought battles between establishment candidates and populist outsiders, simply because congressional primaries have not seen much competition since the middle of the twentieth century (Ansolabehere et al. 2010). Since 2009, a number of Tea Party candidates have successfully challenged the party establishment in the Republican Party, sounding populist themes of "taking our country back" (Skocpol and Williamson 2016). Despite this trend, only a handful of congressional incumbents face a significant primary challenge in any given year (Boatright 2013).

Yet populists—or, more precisely, candidates employing populist appeals- do not necessarily have to defeat an establishment candidate. Populists seeking party nominations for Congress may instead be pushing on an open door. The leadership and campaign committees of both parties take a pragmatic attitude toward nominations inasmuch as they want to nominate someone who can win the seat (Hassell 2017). Given the appeal of populist ideas to the mass public, political consultants even school would-be candidates in the discourse (Kazin 1995, 272).

\section{Prevalence of Populist Rhetoric}

Although no one has systematically studied the use of populist rhetoric in American campaigns below the presidency, there is no doubt that populist tropes are so widespread as to be clichéd. A challenge for research on American populism is distinguishing between candidates who deploy the rhetoric, perhaps in accord with campaign consultants' advice, and those who subscribe to a genuinely populist worldview. ${ }^{6}$

A non-negligible share of members of Congress seek to cultivate a populist image. As one rough gauge, a text search of Congress member profiles in CQ's Politics in America for each Congress between 2006 and 2014 describes 45 members as populist: 33 Democrats and 12 Republicans. The diversity of the group makes it clear that populism embraces a wide range of political identities. Some of the members described as populists are party loyalists or even members of party leadership (e.g., Sen. Byron Dorgan, D-ND, or Sen. Chuck Grassley, R-IA). Others are members known for bucking their party (e.g., Rep. Lincoln Davis, D-TN, Rep. Gene Taylor, D-MS). Some are on the far right (e.g., Sen. Jeff Sessions, R-AL, Sen. Jim Bunning. R-KY, Rep. Ted Yoho, R-FL), some are on the far left (e.g., Rep. Dennis Kucinich, D-OH, Sen. Bernie Sanders, I-VT), and some are centrists (Sen. Jim Webb, D-VA; Rep. Dan Lipinski, D-IL). At two points in recent congressional history (1983-94; 2009-14), there was even an organized, self-identified Populist Caucus in the House of Representatives.

In sum, electoral rules in the United States create an incentive structure that tends to divert populist impulses into the mainstream parties. The difficulty of mounting a third-party challenge deters populists from forming new parties, but the openness of the major parties themselves affords them a viable path to power. As such, the porousness of the major parties blurs boundaries between mainstream and populist politics. In the United States, populist appeals are part of mainstream party politics.

\section{Contemporary Major Party Vulnerabilities}

Comparativists often differentiate between factors affecting the supply of populist parties and candidates (meaning the extent to which voters are presented with populist alternatives) and the demand for populist parties and candidates (meaning the extent to which voters want populist alternatives; Hawkins and Kaltwasser 2017; Mudde and Kaltwasser 2017). Mainstream parties in the contemporary United States may be more vulnerable than at other historical points to populist internal challenge for at least three reasons. First, changes in communication technology are likely to increase the supply of populist candidates. Second, the public's low regard for mainstream parties and leaders makes populist alternatives potentially more attractive, increasing demand. Third, the racialization of the party system may have made mainstream party leaders, who tended to abjure explicitly racialized appeals, vulnerable to populist outflanking.

\section{Evolution in Media}

New media are profoundly democratizing, a development with obvious relevance to the prospects for populist 
candidates and parties. The internet has drastically reduced the costs of political organizing and collective action of all kinds (Farrell 2012). As players who emerge to challenge a "corrupt establishment," populists benefit from an information environment that lowers barriers to entry.

By reducing communication costs, online digital communications have increased the capacity for insurgent political actors to find an audience and disseminate their messages (Cohen et al. 2016). Social media allow "even backbench members [of Congress to] gather a national following with relative ease, and at virtually no cost" (Glassman 2014, 104-5). Likewise, online communications and social media platforms open up new possibilities for political fundraising (Hindman 2005; Wilcox 2008). New media facilitate the cross-national diffusion of ideas, allowing political entrepreneurs to adopt successful frames, appeals, arguments, and strategies across national boundaries (Rydgren 2005).

All types of candidates, establishment and populist alike, benefit from reduced costs for communication and fundraising. However, lower barriers to entry afford greater relative value to insurgents and populists than to mainstream or establishment candidates. Just as campaign finance rules that level the playing field tend to benefit challengers more than incumbents (Gerber 1998), developments that reduce communication and fundraising costs make it easier for new political players to compete. Even in authoritarian regimes, the new communications environment has fueled challenges to established leaders, such as in the Iranian Green Movement, the Gezi Park protests, and the Arab Spring (Lynch 2011; Ruijgrok 2017).

Changes in communications technology stand to increase the supply of populist challengers to establishment parties in the United States, just as they have benefited populists elsewhere (Engesser et al. 2017). Researchers have documented a recent proliferation of nonparty outside groups recruiting, networking, vetting, and training candidates for Congress (Rauch and La Raja 2017). The Tea Party insurgency against establishment Republicans benefited from online communications and fundraising; the groups forming the "Resistance" to Donald Trump do likewise. Today's information environment is advantageous to populist organizing, a factor that may have contributed to the increased prominence of populists in global politics generally.

\section{Unpopular Mainstream Parties and Leaders}

Researchers have focused on "representational deficiencies" in explaining when more citizens tend to become available for populist mobilization (Mair 2013; Rahn and Lavine 2018; Roberts 2017). Established parties across many democracies have lost the capacity to offer meaningful choices, mobilize voters, and command citizens' trust
(Dalton and Weldon 2006; Grzymala-Busse 2017b; Kuo 2018; Mair 2013; Roberts 2007), factors that have contributed to the rise of populist alternatives. Like their counterparts in so many other democracies, neither the major parties in the United States nor their most visible leaders are popular.

Figure 1 presents Gallup data on American attitudes toward the Democratic and Republican Parties from 2001 to 2017. The trend lines are unmistakable. For both Republicans and Democrats unfavorable attitudes have increased markedly, and favorable attitudes have declined. Neither party has garnered a favorable majority since 2009; the Republican Party has not been above 50\% since 2004. Outright majorities have generally held unfavorable views of the Republican Party since 2006 and of the Democratic Party since 2010.

Table 1 presents data on the job approval ratings of leaders of the major parties in American politics. The leaders of both parties consistently fall short of majority approval. Since 2005 , presidents have usually garnered approval ratings below $50 \%$ overall in national opinion polls; congressional leaders have fared far worse, with approval rarely reaching $40 \%$ and even sometimes falling below $25 \%$.

Looking at the parties internally, only presidents consistently garner majority approval from respondents who identify with their party. Congressional party leaders, meanwhile, are generally not well loved even by their fellow partisans. Intraparty approval of congressional leaders regularly falls below $50 \%$.

Given the institutional obstacles that stand in the way of new parties forming and successfully contesting for office in American politics, the low approval of mainstream parties and leaders will not likely fuel the emergence of new parties, as it has in other democracies. But the weakness of US party leaders, both in the aggregate and with their own voters, offers favorable terrain for populist candidacies. Party leaders with such soft public support do not stand on strong footing when and if they seek to fend off antiestablishment challenges in nomination contests.

\section{Major Party Convergence in a Racialized Party System}

One of the most striking developments in the American party system since the 1990s has been the remarkable divergence in the racial and ethnic composition of the two parties in the mass electorate. Ironically, this demographic divergence occurred in a context in which, at least before 2016, the national leadership of the Republican and Democratic Parties had been trending toward closer convergence on policy issues relating to race and ethnicity, both in terms of party positions and rhetoric.

The comparative literature on populism often focuses on the dissatisfaction that arises when the mainstream 
Figure 1

Public Attitudes toward the Major Parties, 2001-17

A 65

60

55

50

45

40

35

30

25

20

2001200220032004200620082009201020132014201520162017

B

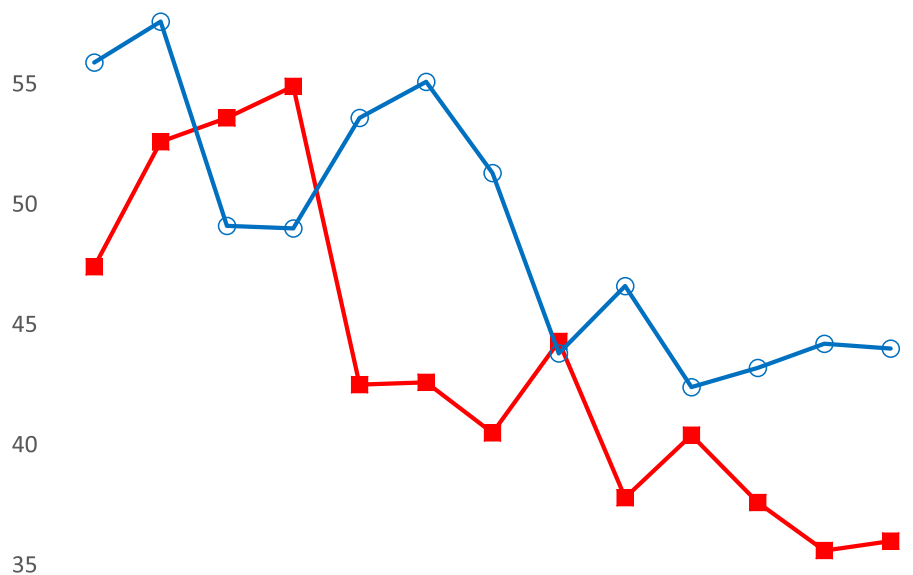

35

30

25

20
-Favorable opinion of Republican Party

(\%)
(\%)

-Unfavorable Opinion of Democrat Party

(\%)

Source: Gallup polling. 
Table 1

Public Attitudes toward Major Party Leaders

\section{Overall \\ approval}

(\%)

\section{Overall \\ disapproval}

(\%)
In-party

approval

(\%)
In-party

disapproval

(\%)

\section{Paul Ryan (R-WI)}

June 2018

April 2017

November 2016

November 2015

Nancy Pelosi (D-CA)

June 2018

September 2013

October 2010

January 2007

40

46

48

42

29

39

29

44

Mitch McConnell (R-

$\mathrm{KY})$

June 2018

August 2017

October 2015

September 2013

March 2010

Chuck Schumer (D-

NY)

June 2018

April 2017

John Boehner (R-

$\mathrm{OH})$

October 2015

September 2013

November 2010

Harry Reid (D-NV)

October 2014

September 2013

November 2010

Dennis Hastert (R-IL)

October 2006

September 2002

February 1999

Tom Daschle (D-SD)

September 2002

June 2001

Dick Gephardt (D-

MO)

September 2002

October 2000

October 1998

May 1998

Newt Gingrich (R-

\section{GA)}

October 1998

January 1997

December 1994

\section{Presidents}

Donald Trump (R)

2018 average

2017 average

Barack Obama (D)

2016 average

2015 average
24

23

18

35

32

29

31

36

54

54

31

37

34

21

33

25

27

30

31

39

34

40

42

48

42

32

29

40

39

51

46

$\begin{array}{cc}37 & 42 \\ 48 & 44 \\ 66 & 4 \\ * & * \\ 47 & 40 \\ 50 & 15\end{array}$
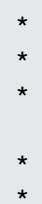

10

15 
Table 1

Public Attitudes toward Major Party Leaders (continued)

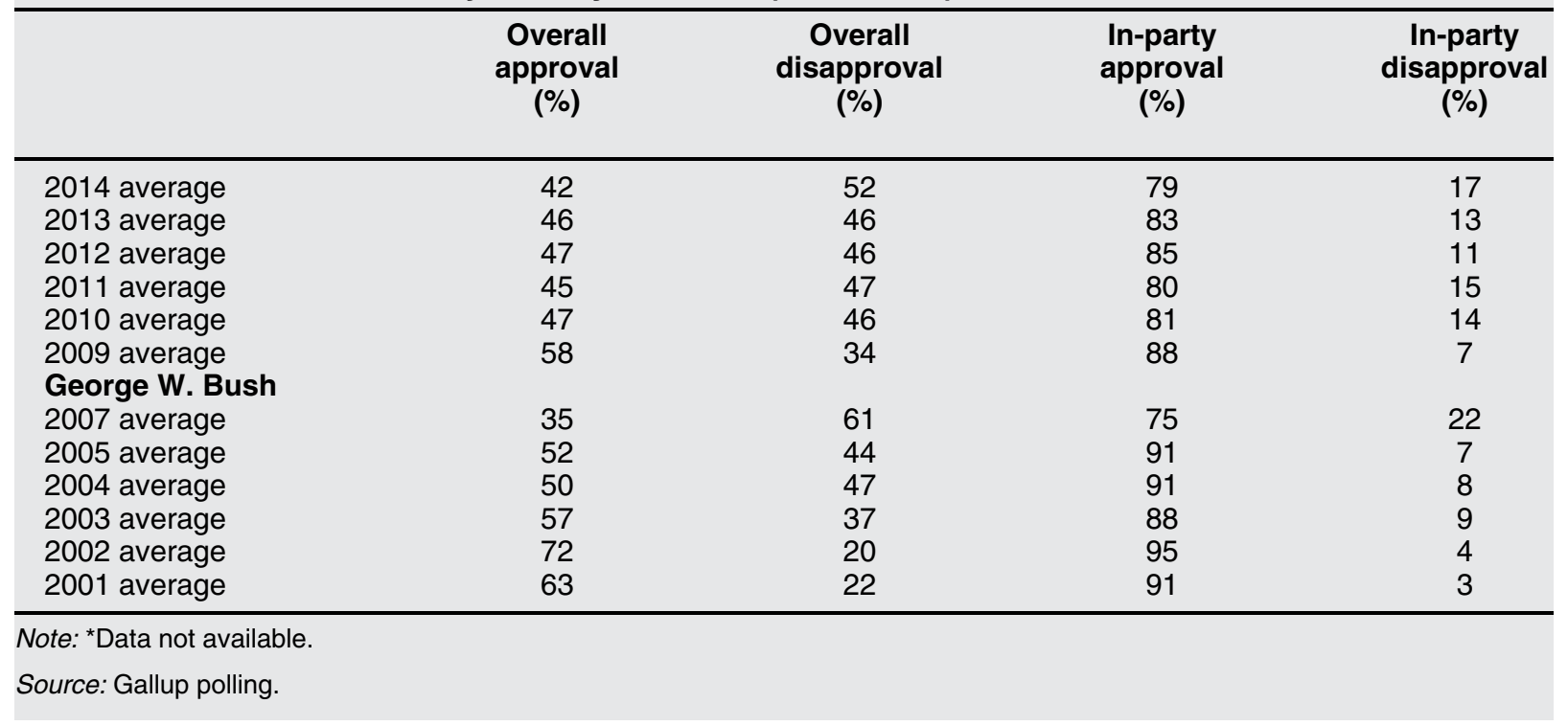

parties "converge" on the left-right spectrum. When established parties and leaders fail to offer policy alternatives on issues citizens care about, the voters are more likely to look outside the mainstream for answers (Kaltwasser 2015). When parties of the left impose austerity and market liberalization, for example, they can become vulnerable to outflanking by populist outsiders (Roberts 2017, 293). Left-right convergence is a matter of perception as much as of reality. But it is clear from party platforms and congressional agendas that Republicans and Democrats have long presented distinct alternatives on questions of income tax progressivity and the overall tax burden, as well as on the role of government in the social provision of health care and education.

Racial Policy and Rhetoric. By contrast to tax and social welfare policy, the national leaders of the two major US parties had moved toward convergence on issues of race and immigration in the decades immediately preceding 2016. Although the parties were far from identical on these issues, they shared wider swaths of overlap. Racially charged issues such as crime, welfare, school busing, and affirmative action figured less prominently in twenty-firstcentury party politics than they had in the 1970s and 1980s. Votes on racial issues also comprised a declining share of the congressional roll-call agenda since the late 1980s (Lee 2009, 168-70).

Some basic questions about civil rights and racial policy had seemingly been resolved. Neither Republican nor Democratic Party leaders advocated significant rollback of the landmark civil rights reforms of the 1960s. Reauthorizations of the Voting Rights Act occurred under Presidents Ronald Reagan, George H. W. Bush, and George W. Bush with strong bipartisan majorities.
Analyzing substantive policy disagreements in Congress since the late nineteenth century, Bateman, Clinton, and Lapinski (2017) conclude that the second half of the twentieth century saw significantly reduced party polarization on race issues. Although the parties continued to diverge on policies with differential racial impact such as voter ID legislation, they no longer debated fundamental questions about African American voting rights, equal access to public accommodations, or whether there is a federal role in deterring racial discrimination.

Before 2016, the two parties also did not offer clear alternatives on immigration. The Republican Party was unquestionably more hawkish on illegal immigration, but the two parties did not offer distinct answers to the more fundamental question of the level of legal immigration. In the United States, as in several other settler societies, writes Freeman $(1995,888)$, "there is a marked tendency to develop an interparty consensus (almost always expansionary, sometimes status quo) in order to take immigration out of politics." Ideologically heterogeneous, bipartisan coalitions enacted the major immigration policies in place since the 1980s (Tichenor 1994).

Under unified Republican control in 2006, President George W. Bush led a bipartisan push for comprehensive immigration reform, linking enhanced border security with a path to citizenship for most undocumented immigrants. A bipartisan group of senators-the "Gang of Eight"-negotiated a similar reform package in 2013, which passed the Senate by a wide margin (68-32). In the end, both the 2006 and 2013 reforms were halted by Republican opposition in the House of Representatives. The long stalemate on US immigration policy owes more 
to internal divisions in the Republican Party than to party polarization.

Looking beyond policy to rhetoric, major party convergence pre-2016 was even more evident. Racially divisive rhetoric had become nearly taboo in mainstream party politics. Political leaders in both parties steered clear of explicitly racial or ethnonationalist appeals (Mendelberg 2001). Haney-López (2014) points to a "convergence" between the parties during the 1990s and early 2000s: Bill Clinton emphasized his southern heritage as a means of reassuring racially conservative whites (107), while George W. Bush pursued a "strategy of toning down the racism and reaching out to nonwhites" (116). Emerging from the George W. Bush presidency, the conventional wisdom among Republican Party elites was that the party needed to do a better job competing for minority votes. In the wake of its 2012 presidential election defeat, for example, the Republican National Committee's (2013) "Autopsy Report" advocated for a more welcoming posture toward racial minorities. ${ }^{7}$

Racial Divergence in the Electorate. This bipartisan convergence on key racial and ethnic issues and the norm against the use of racially divisive rhetoric persisted in American national politics, even as the parties in the electorate continued to grow more distinct from one another along lines of race and ethnicity.

Drawing on data from the American National Election Study, figure 2 tracks the racial composition of each party between 1950 and 2016, benchmarked against the racial composition of the country as a whole, as gauged by the US Census. ${ }^{8}$ The right-most panel displays the changing white proportion of the national population, as well as of respondents who align with the Democratic and Republican Parties over time. The marked drop in the white share of the population, from $90 \%$ white in 1950 to $61 \%$ white in 2016, is designated with a heavy line. As is evident here, from 1950 to 1980 , the white share of the Democratic Party declined steadily in tandem with the white share of the national population. After 1980, whites began to comprise a smaller proportion of the Democratic Party than of the national population as a whole.

Meanwhile, since the late 1980s, demographic change has largely passed the Republican Party by. In 2016, $85 \%$ of Republicans were still white, just as in 1990. The increasingly stark gap between the racial composition of the Republican party and the country as a whole is also evident in the panels showing the black and Hispanic shares of the parties and the electorate. The GOP remains an overwhelmingly white party in a country that has become much more racially and ethnically diverse.

As early as 1989, Huckfeldt and Kohfield (1989, 2) wrote that race was driving out class as "the most significant factor in electoral politics." Since 1990, the American electorate has grown progressively more racially

\section{Figure 2 \\ Party Composition by Race, 1950-2016}

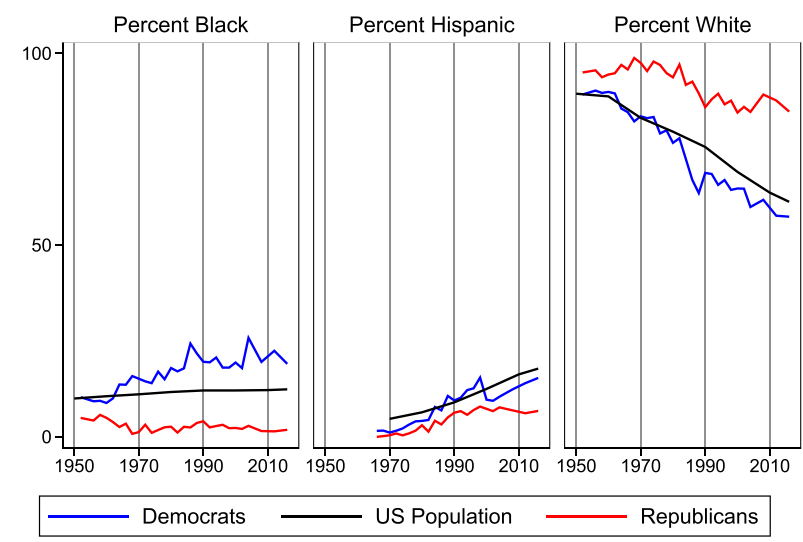

Source: American National Election Surveys and the US Census.

and ethnically diverse, and the "diversity gap" between the parties has grown ever wider. Figure 3 displays the divergence between the white percentage of each party and the national population. The parties' racial differences are also starkly reflected in Congress, where minorities make up fully 38 percent of Democratic members but a mere 5 percent of Republicans (Manning 2019).

As is evident here, these shifts in the racial composition of the parties occurred gradually over decades. They were driven by both "bottom-up" activism at the parties' grassroots and "top-down" efforts of party leaders. Dating back to Nixon's "Southern Strategy," Republican leaders had sought to draw racially conservative southern whites into the Republican Party (Frymer and Skrentny 1998). To do so, candidates employed symbols, "dog whistles," and coded appeals tapping into racial prejudice and stereotypes (Mendelberg 2001), rather than presenting stark policy alternatives on racial issues. ${ }^{9}$ At the same time, grassroots movements both North and South mobilized in reaction to desegregation, especially against school busing (Lassiter 2006). The resulting "politics of suburban secession" (Kruse 2005) reshaped conservative ideology itself (Crespino 2007; Lowndes 2008). Over time, white voters' attitudes toward race emerged as a much stronger predictor of their partisan attachments, with white racial conservatives more likely to identify as Republicans and white racial liberals more likely to identify as Democrats (Tesler 2016).

The upshot of these long-term demographic and ideological changes is a party system increasingly cleaved along racial lines and thus primed to express racial and ethnic policy differences. Whites and nonwhites hold different views on many political issues and priorities. On questions involving racial discrimination and inequality, for example, whites and blacks are "worlds apart" (Pew Research Center 2016). A party system in which racial 


\section{Figure 3 \\ White Share of the Major Parties Relative to the US Population, 1952-2016}

30

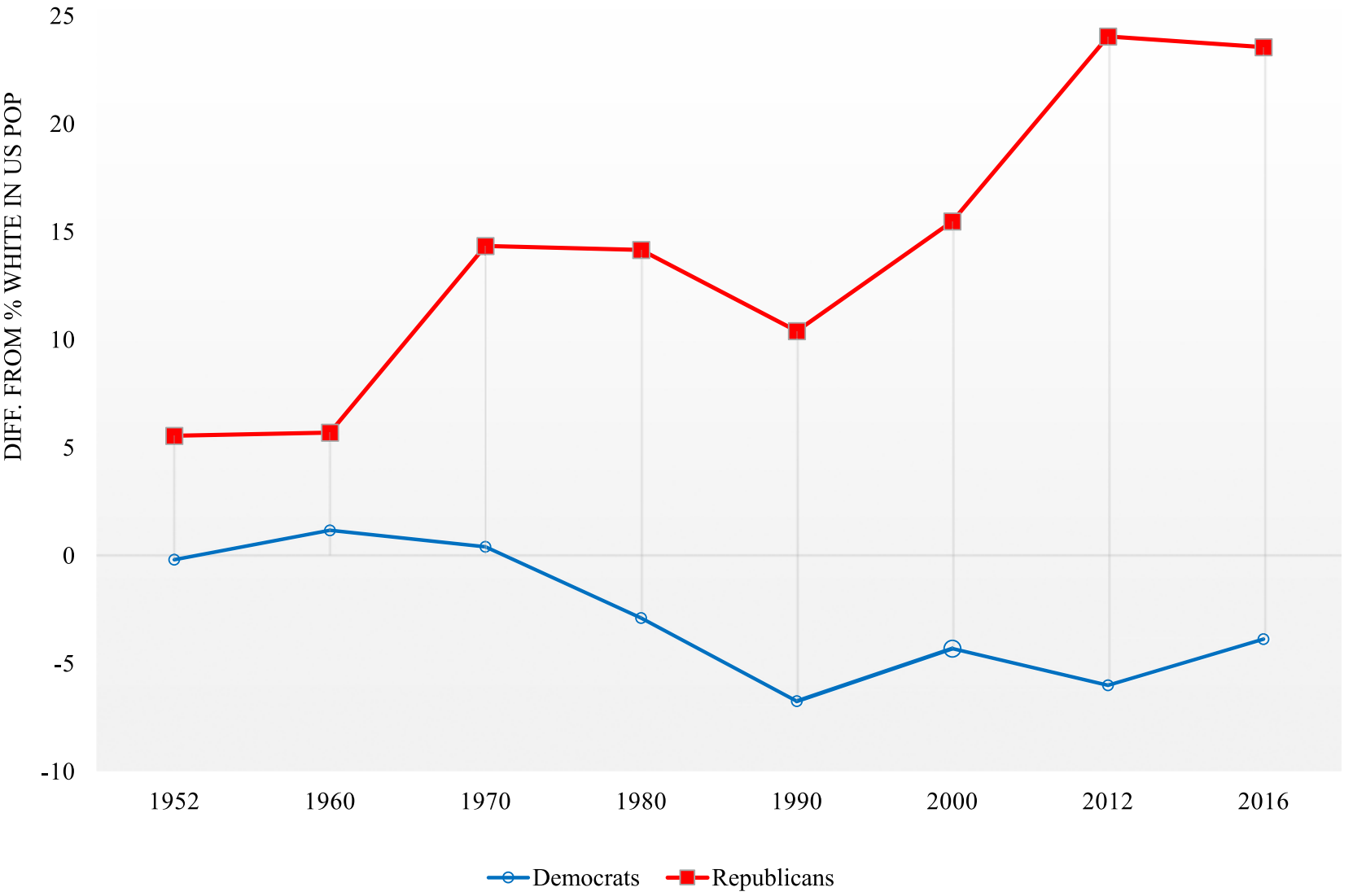

Source: American National Election Surveys and the US Census.

minorities made up equivalent shares of both major parties would be less inclined toward conflict on issues that divide whites from nonwhites, just as the Labour and Conservative parties in the post-2016 United Kingdom-each internally divided on Brexit-long declined to present clear alternatives on the country's membership in the European Union. Rather than suppressing racial conflict, however, a party cleavage that sorts voters by race will tend to emphasize and even exacerbate it.

Major Party Vulnerability to Outflanking. Considering the deep racial gap between the parties in terms of electoral composition and the relatively modest gap between mainstream party leaders on racial policy and the use of racialized rhetoric, it should not be surprising that the Republican establishment would be vulnerable to outflanking. Since the 1990s, Republican leaders had sought to tamp down party conflict over race and immigration while simultaneously leading a party that is overwhelmingly white and increasingly conservative on these issues. In so doing, they likely opened a "representation gap" ripe for populist exploitation. Given the radical porousness of party nomination processes in the United States, elite gatekeepers cannot veto party nominations if racist or ethnonationalist appeals successfully activate a majority of primary voters (Schlozman and Rosenfeld 2019).

The outlines of a more populist, less racially inclusive politics appeared in more than embryonic form in the 2016 elections. Even before he announced his presidential bid, Trump had long promoted the "birther" conspiracy claiming that President Obama was not born in the United States. Over the course of his campaign, Trump violated the norms of liberal democracy in numerous ways. He launched his campaign in June 2015 with a speech labeling Mexican immigrants rapists and criminals. He called for a "total and complete shutdown of Muslims entering the United States." ${ }^{\prime 0} \mathrm{He}$ claimed that a judge of Mexican descent could not be fair. ${ }^{11}$ Repeatedly at campaign rallies, he expressed nostalgia for a time when extralegal violence could be deployed against protestors. ${ }^{12}$ In each of these controversies, Trump 
was denounced by mainstream opinion leaders and Republican officeholders. But giving voice to such sentiments allowed him to forge a unique bond of trust and "authenticity" with important elements in the Republican base and create favorable contrasts with establishment Republican leaders and officeholders (Sides, Tesler, and Vavreck 2018).

Considering the long-term changes in the party system evident in figures 2 and 3 , it seems likely that a candidate using such "politically incorrect" appeals would have emerged eventually, even had Trump not proved successful in 2016. Willing to violate norms against the use of racialized rhetoric, Trump was able to offer primary voters a product that other Republican elites refused to supply. Those appeals strengthened his populist, anti-elite credentials and probably contributed to his success in winning the nomination.

\section{Obstacles to Authoritarian Populism}

Although it is extremely difficult for third parties to successfully challenge major parties, there is nothing about the US system that keeps populists out of office. When they get into office, however, they will normally arrive under the auspices of one of the major parties. The question, then, is how much threat they pose to American democracy.

Given how extensively the US constitutional system fragments political power, Americanists have tended to worry far more about gridlock and ungovernability than authoritarianism (e.g., Binder 2003). Under its separation of powers, bicameralism, and strong federalism, governance in the United States requires leaders to obtain cooperation from an array of independent actors, all with their own bases of political power and formal authority. Party polarization stresses any political system that puts such a premium on negotiating across veto points (McCarty 2019). Populist leaders tend to exacerbate political and societal polarization (Weyland and Madrid 2019). A more populist party politics centered around racial and ethnic identity will likely deepen these challenges (Mason 2018) and thereby degrade the performance of American governing institutions.

In the wake of the 2016 elections, scholars have been more willing to consider the possibilities for authoritarian populism (Miller, Szakonyi, and Morgenbesser 2018) and democratic erosion in the United States (Carey et al. 2019). In How Democracies Die, Levitsky and Ziblatt (2018) envision a scenario by which an authoritarian leader, standing at the helm of a party that controls both chambers of Congress and a majority on the Supreme Court, politicizes election administration and law enforcement to entrench permanent control of the federal government. Many experts assess that the United States has seen some democratic backsliding in recent years, precisely what one would expect based on the comparative research on the effects of populist in power (Carey et al. 2019).

Although Levisky and Ziblatt are right to caution against complacency in a world where many democracies have deteriorated (Diamond 2015), the American political system still maintains formidable obstacles against authoritarianism, populist or otherwise. Albeit imperfect, these obstacles are likely to frustrate any but an overwhelmingly popular leader. It is hard to think of a political system that sets higher hurdles to single-party control than the American constitutional system. The "American Hybrid" in Dahl's (2001, 110-16) formulation requires three concurrent, separately elected majorities: majorities of the House and Senate, each resting on a distinct base of apportionment, and control of the presidency. To this list, one might add the need for a Supreme Court majority as well.

Comparative politics scholars have identified two dominant pathways for post-Cold War democratic erosion (Bermeo 2016): executive aggrandizement and strategic election manipulation. Both these paths to democratic backsliding are more open at the state than at the federal level. ${ }^{13}$ At the federal level, populist electoral success will more likely degrade governmental capacity via deeper polarization than empower an authoritarian regime.

\section{Executive Aggrandizement}

Executive aggrandizement "occurs when elected executives weaken checks on executive power one by one, undertaking a series of institutional changes that hamper the power of opposition forces to challenge executive preferences" (Bermeo 2016, 10-11). Although presidential power is enhanced when Congress is gridlocked or compliant, it is hard to envision the United States embracing the transformative institutional changes that have degraded democracies to "competitive authoritarianism" (Levitsky 2010).

In countries where executive aggrandizement has occurred, it has often proceeded via democratic means -through national elections, referendums, and legitimate lawmaking processes. To secure political hegemony, Erdoğan employed a 2017 popular referendum to transform Turkey from a parliamentary to a presidential system of government, with himself as elected dictator. As another example, Orban's radical overhaul of the Hungarian system was reinforced in 2018 by a landslide reelection to a third term along with a two-thirds parliamentary majority.

The US presidency is a powerful office with vast authority over domestic regulation and foreign affairs. Recent presidents have made bold use of their unilateral powers, in some cases laying claim to a legal theory of the "unitary executive" (Howell 2003; Rudalevidge 2006). But in comparative perspective, the US Congress is 
unusually strong, and the president is relatively weak (Shugart and Carey 1992, 148-66). The US president has very limited power to control the federal budget or set the congressional agenda and obtain votes on administration priorities. The president cannot dismiss either chamber of Congress.

It would be very difficult to substantially augment the presidency's powers. The procedural barriers to constitutional change in the United States are extraordinarily high (Lutz 1994). The president is constitutionally limited to two terms. Only an overwhelmingly popular president would stand a chance at achieving a significant expansion of formal executive power, along the lines of the constitutional changes wrought in Hungary and Turkey.

But even bare majority support is outside presidents' reach most of the time. Although a declining proportion of Americans self-identify with a major party, the American electorate is not volatile. Presidential elections are decided within a narrow range. There has not been a landslide presidential election in American politics since 1984, when Ronald Reagan won a national majority of $58.8 \%$. As shown in Table 1, presidents spend much of their time in office near or below 50\% approval in public opinion polls.

Populist leaders put executive checks to the test and often undermine horizontal constraints on their power. President Trump fits the populist mold in this respect, breaking long-standing norms in his use of executive power over trade policy and emergency decrees, among others. Not surprisingly, expert surveys during the Trump administration point to a decline of confidence in the efficacy of judicial and legislative constraints on the executive (Carey et al. 2019, 11-14). But Trump has not broken free of the institutional limits on presidential consolidation of power, including separate elections for national offices, bicameralism, federalism, and an independent judiciary.

Separate Elections. Members of Congress win office as individual candidates in single-member constituencies on the basis of their own campaign appeals and pledges, not as part of party teams bound to a national leader or platform. They usually run stronger in their own constituencies than do their party's presidential candidate. Additionally, midterm elections almost always weaken the president's party in Congress, a key reason why presidents' political capital tends to decline over time (Light 1999). Given the close division of party support in the electorate, the US national government has been under divided party control three-quarters of the time since 1980. Unified governments do not endure long.

The Trump presidency fits the usual pattern. Trump faced significant congressional resistance to his legislative agenda even in unified government during his first two years in office (Edwards 2018), and congressional resistance further hardened after the 2018 midterms. The upshot is President Trump's control over national government was weaker in 2019 than it had been in 2017, consistent with the normal decay in presidential authority over time.

Bicameralism. The bicameral Congress is not a majorityrule institution. The president's party opposition is often able to block a president's legislative initiatives, even in unified government. Bicameral disagreement blocked or diluted much of President Trump's proposed legislation, including the efforts to repeal and replace Obamacare, roll back financial regulatory reforms, cut domestic discretionary spending, and impose work requirements on food stamp recipients.

Federalism. The federal system usually operates so that presidents face a substantial number of states controlled by their party opposition. Considering the degree of federalstate cooperation required in most federal policy implementation, opposed state governments have numerous tools to block or dilute national policies (Robertson 2011). Presidents and parties in power at the federal level routinely struggle to overcome "uncooperative federalism" as they seek to impose national policy (Bulman-Pozen and Gerken 2009, 1256). The Trump administration encountered strong political and legal opposition from Democratic-leaning states challenging administration policy on immigration, environment, and health policy.

Independent Judiciary. Presidents regularly find their laws and executive actions bogged down in judicial disputes or overturned by the federal courts. Indeed, federal courts halted or reversed an array of President Trump's executive orders and administrative actions. Courts ended the separation of families at the border, disallowed the long-term detention of migrant families, and blocked the administration from ending Temporary Protected Status for migrants from Haiti, El Salvador, Honduras, and Sudan. A federal judge required the administration to restore the Obama-era program protecting "Dreamers" while litigation is pending. A series of adverse rulings blocked the Trump administration's Environmental Protection Agency from rolling back several health and environmental safety regulations.

In sum, the difficulties of consolidating national power in American politics are formidable. Even Franklin Roosevelt-elected by a landslide in 1932 in the midst of national crisis, presiding over overwhelming majorities in Congress, reinforced by an anomalous midterm election in 1934 that did not deplete his party's ranks, and triumphantly reelected by an even greater landslide in 1936 - found his domestic agenda largely halted in five years' time. Although one can imagine an even more popular leader, with broader and more enduring support, it would be outside American experience to date.

\section{Strategic Election Manipulation}

As a second form of democratic backsliding, strategic election manipulation "denotes a range of actions aimed at 
tilting the electoral playing field in favor of incumbents" (Bermeo 2016, 13). US electoral law is hardly free of deck stacking (Issacharoff, Karlan and Pildes 2012). The political interests of incumbents and majority parties influence policies regarding voting (Hicks et al. 2016), ballot access (Lewis-Beck and Squire 1995), campaign finance (La Raja 2008), and legislative districting (Cox and Katz 2002).

Nevertheless, a president or majority party in Congress cannot wield strategic election manipulation to cement political control at the federal level for the simple reason that the federal government has so little power over election administration. Voting procedures and voter registration, legislative districting, and ballot access are regulated at the state level and administered at the local level. States are jealous of their authority in this arena. When President Trump assembled a commission on election integrity that represented a potential effort at deck stacking, it failed to obtain cooperation from state election officials, including even in Republican states, ${ }^{14}$ got bogged down in lawsuits, and was dissolved in less than a year.

Because authority over election law is so decentralized, a party with unified control of the national government cannot impose nationwide rules tilting the overall electoral playing field to its advantage. In states where one party is dominant, it may adopt electoral rules favorable to its interests. Along these lines, since 2004 Republican-controlled states have enacted a variety of "anti-voter fraud" measures that disproportionately burden poor, minority, and Democratic voters (Biggers and Hanmer 2017). These moves represent a troubling form of democratic backsliding and have contributed to downgrades in the Freedom House rating of US democracy. ${ }^{15}$ They have alarmed voting rights advocates aware of the country's long history of minority disfranchisement. Such moves, however, have proved to be of limited efficacy in reducing minority turnout (Grimmer et al. 2018; Highton 2017). Institutional engineering of this type often does not work as intended (Gelman and King 1994).

Even when partisan deck stacking is effective, strategic election manipulation would not suffice to entrench a party at the federal level, because parties can engineer this kind of deck stacking in states only where they are already strong and thus likely to win anyway. They have great difficulty executing these maneuvers in swing states, much less in states that lean toward the opposing party. ${ }^{16}$ The state-by-state nature of these battles limits opportunities for a majority party or would-be authoritarian leader to entrench national power against electoral reversal. The decentralization of power over election administration undermines the quality of American democracy, but it also hampers federal efforts at strategic election manipulation.

\section{Taking Stock of Populism's Potential Threats}

Americans are susceptible to populist appeals. Although third-party candidacies are rarely viable, populists are able to win power within the existing mainstream parties. Indeed, both the supply and demand for populism in American politics have likely increased. Short of overwhelming public support, however, it seems unlikely that a populist party or president would be able to centralize authoritarian power over American national government.

Democratic backsliding in American politics is unlikely to proceed very far, in great part because the constitutional system puts up so many obstacles in the way of democratic majorities. But those institutional constraints do not neutralize populism's threats. Rather than a slide toward autocracy, populist perils for American democracy are more likely to entail erosion of the norms of a racially and ethnically inclusive liberalism. A more populist politics in a party system increasingly defined by race and identity menaces the interests of minorities and immigrants. But short of minority disfranchisement, American politics can become less inclusive and tolerant without loss of democratic form.

As such, populism's challenges to American democracy likely center more on the performance of its democratic institutions than their persistence. A racialized party system in an electorate with a questionable commitment to liberal values is a troubling development. It is difficult to manage racial tensions in a democracy in any case, much less when race becomes a principal line of political cleavage (Rabushka and Shepsle 1972). After all, the United States only became a fully multiethnic democracy with the 1965 Voting Rights Act, following a long and tortured process of democratization (Bateman 2018; King et al. 2009; Mickey 2015; Mickey, Levitsky, and Way 2017). Given this history, illiberal democracy probably has a mass constituency in the United States, as it does in Hungary, Poland, the Philippines, and elsewhere (Zakaria 1997).

It seems almost certain that Trump's astonishing success will point the way to future ambitious politicians. Yet Trump is also an unpopular president. He has never commanded anything like the domestic support of Erdoğan, Russian president Vladimir Putin, Indian prime minister Narenda Modi, or Philippine president Rodrigo Duterte. It is simply too early to say whether the politics of 2016 is a harbinger of the future. But with his truculent populism and willingness to exploit racial resentments, Trump was able to appeal to attitudes that public opinion scholars have long known were present in the American electorate but had not been courted by 
mainstream politicians in recent decades. Going forward, we are likelier to see a more illiberal, racially inflected party politics than an authoritarian consolidation of executive power.

\section{Notes}

1 For recent reviews of the literature, see Golder 2016; Kaltwasser et al. 2017.

2 There are no runoffs in presidential elections or for most seats in Congress. Georgia and Louisiana have runoff general elections for Congress. To elect their members, California and Washington state hold a first-round primary election in which candidates of all parties compete, with the top-two vote getters advancing to the general election.

3 See William Bradley, "Jerry Brown for President: The Way We Were," Huffington Post [blog], January 17, 2014, https://www.huffingtonpost.com/williambradley/jerry-brown-for-president_b_4619652.html.

4 Editorial, "Huckabee's Revival Meeting," Wall Street Journal, January 5, 2015.

5 Tamas and Hindman (2014) show that more stringent ballot access laws cannot explain the decline in third-party candidates for the House of Representatives.

6 A possible path forward is to analyze the prevalence of populist themes in politicians' speeches to range politicians along a continuum from strongly to modestly to not at all populist. See Bonikowski and Gidron 2015; Hawkins and Kaltwasser 2018.

7 See Republican National Committee, Growth and Opportunity Project, March 2013, http://online.wsj.com/public/resources/documents/RNCreport03182013.pdf.

8 Of respondents identifying with each party in ANES surveys, the figure displays the proportion black, Hispanic, and white. "Leaners" are classified as identifying with the party they generally prefer.

9 No presidential election campaign since 1964 - in which Goldwater opposed the landmark Civil Rights Act while Johnson championed it-has posed as clear a policy choice on racial issues.

10 See Jenna Johnson, "Trump Calls for 'Total and Complete Shutdown of Muslims Entering the United States," Washington Post, December 7, 2015.

11 See Brent Kendall, "Trump Says Judge's Mexican Heritage Presents 'Absolute Conflict,'” Wall Street Journal, June 3, 2015.

12 See Ainara Tiefenthaler, "Trump's History of Encouraging Violence," Times Video, NYTimes.com, March 14, 2016, https://www.nytimes.com/video/us/ 100000004269364/trump-and-violence.html.

13 State governments have at times tended toward populist authoritarianism, most famously Louisiana under the governorship of Huey Long (1928-32). On "authoritarian enclaves" in the one-party South, see Mickey 2015.

14 Mississippi's Republican secretary of state Delbert Hosemann's response to a commission data request was to tell the commission to "go jump in the Gulf of Mexico and [that] Mississippi is a great State to launch from." See Brooke Seipel, "Mississippi Official: Fraud Commission Can 'Go Jump in Gulf of Mexico," The Hill, June 30, 2017.

15 See the US profile, Freedom in the World 2018, Freedom House, https://freedomhouse.org/report/ freedom-world/2018/united-states.

16 States with strict voter identification rules are Alabama, Georgia, Indiana, Kansas, Mississippi, North Dakota, Tennessee, Virginia, Texas, and Wisconsin. Of these, only Virginia and Wisconsin do not strongly lean Republican.

\section{References}

Ansolabehere, Stephen, John Mark Hansen, Shigeo Hirano, and M. James. Snyder Jr. 2010. "More Democracy: The Direct Primary and Competition in US Elections." Studies in American Political Development 24: 190-205.

Azari, Julia. 2017. "The Political Geography of American Populism." Workshop on Global Populisms as a Threat to Democracy, Stanford University, November 3-4, 2017. https://fsi.stanford.edu/global-populisms/docs/ global-populisms-conference-memos.

Bartels, Larry. 2017. "The 'Wave' of Right-Wing Populist Sentiment Is a Myth," The Monkey Cage [blog], July 21. https:/www.washingtonpost.com/news/monkey-cage/ $\mathrm{wp} / 2017 / 06 / 21 /$ the-wave-of-right-wing-populist-sentiment-is-a-myth/?utm_term $=.4 \mathrm{a} 2301 \mathrm{~d} 2 \mathrm{c} 1 \mathrm{a} 3$.

Bateman, David A. 2018. Disenfranchising Democracy: Constructing the Electorate in the United States, the United Kingdom, and France. New York: Cambridge University Press.

Bateman, David A., Joshua D. Clinton, and John S. Lapinski. 2017. "A House Divided? Roll Calls, Polarization, and Policy Differences in the US House, 1877-2011." American Journal of Political Science 61: 698-714.

Bermeo, Nancy. 2016. "On Democratic Backsliding." Journal of Democracy 27 (January): 5-18.

Biggers, Daniel R. and Michael J. Hanmer. 2017. "Understanding the Adoption of Voter Identification Laws in the American States." American Politics Research 45: 560-88.

Bimes, Terri and Quinn Mulroy. 2004. "The Rise and Decline of Presidential Populism." Studies in American Political Development 18: 136-59.

Binder, Sarah A. 2003. Stalemate: Causes and Consequences of Legislative Gridlock. Washington, DC: Brookings Institution Press. 
Boatright, Robert G. 2013. Getting Primaried: The Changing Politics of Congressional Primary Challenges. Ann Arbor: University of Michigan Press.

Bonikowski, Bart and Noam Gidron. 2015. "The Populist Style in American Politics: Presidential Campaign Discourse, 1952-1996." Social Forces 94(4): 15931621.

Bulman-Pozen, Jessica and Heather K. Gerken. 2009. "Uncooperative Federalism." Yale Law Journal 118: 1256-1583.

Carey, John, Gretchen Helmke, Brendan Nyhan, Mitchell Sanders, and Susan Stokes. 2019. "Searching for Bright Lines in the Trump Presidency." Perspectives on Politics. https://doi.org/10.1017/S153759271900001X.

Clanton, Gene. 1984. "'Hayseed Socialism' on the Hill: Congressional Populism, 1891-1895." Western Historical Quarterly 15: 139-62.

Cohen, Marty, David Karol, Hans Noel, and John Zaller. 2008. The Party Decides. Chicago: University of Chicago Press.

_. 2016. "Party versus Faction in the Reformed Presidential Nominating System." P.S.: Political Science \& Politics 49(4): 701-8.

Cox, Gary W. and Jonathan N. Katz. 2002. Elbridge Gerry's Salamander: The Electoral Consequences of the Reapportionment Revolution. New York: Cambridge University Press.

Crespino, Joseph. 2007. In Search of Another Country: Mississippi and the Conservative Counterrevolution. Princeton, NJ: Princeton University Press.

Dahl, Robert A. 2001. How Democratic Is the American Constitution? New Haven: Yale University Press.

Dalton, Russell J. and Steven A. Weldon. 2005. "Public Images of Political Parties: A Necessary Evil?” West European Politics 28(5): 931-51.

Diamond, Larry. 2015. "Facing up to the Democratic Recession." Journal of Democracy 26: 141-55.

Duverger, Maurice. 1986. "Duverger's Law: Forty Years Later." On Electoral Laws and Their Political Consequences, eds. Bernard Grofman and Arend Lijphart, 6984. New York: Agathon Press.

Dzur, Albert W. 2010. "The Myth of Penal Populism: Democracy, Citizen Participation, and American Hyperincarceration." Journal of Speculative Philosophy 24(4): 354-79.

Edwards, George C. 2018. “'Closer' or Context? Explaining Donald Trump's Relations with Congress.” Presidential Studies Quarterly 48: 456-79.

Engesser, Sven, Nicole Ernst, Esser Frank, and Florin Büchel. 2017. "Populism and Social Media: How Politicians Spread a Fragmented Ideology." Information, Communication \& Society 20: 1109-26.

Farrell, Henry. 2012. "The Consequences of the Internet for Politics." Annual Review of Political Science 15: 3552.
Freeden, Michael. 1998. "Is Nationalism a Distinct Ideology?” Political Studies 46: 748-65.

Freeman, Gary P. 1995. "Models of Immigration Politics in Liberal Democratic States." International Migration Review 29: 881-902.

Frymer, Paul and John David Skrentny. 1998. "CoalitionBuilding and the Politics of Electoral Capture during the Nixon Administration: African Americans, Labor, Latinos." Studies in American Political Development 12 (Spring): 131-61.

Gelman, Andrew and Gary King. 1994. "Enhancing Democracy through Legislative Redistricting." American Political Science Review 88: 541-59.

Gerber, Alan. 1998. "Estimating the Effect of Campaign Spending on Senate Election Outcomes Using Instrumental Variables." American Political Science Review 92(2): 401-11.

Gerring, John. 1998. Party Ideologies in America, 18281996. New York: Cambridge University Press.

Glassman, Matt. 2014. "Tweet Your Congressman: The Rise of Electronic Communications in Congress." In The Evolving Congress, Congressional Research Service, Committee on Rules and Administration, United States Senate, 113th Congress, 2d Session, 113-30, pp. 104-5.

Golder, Matt. 2003. "Explaining Variation in the Success of Extreme Right Parties in Western Europe." Comparative Political Studies 36: 432-66.

. 2016. "Far Right Parties in Europe." Annual Review of Political Science 19: 477-97.

Grattan, Laura. 2016. Populism's Power: Radical Grassroots Democracy in America. New York: Oxford University Press.

Grimmer, Justin, Eitan Hersh, Marc Meredith, Jonathan Mummolo, and Clayton Nall. 2018. "Obstacles to Estimating Voter ID Laws' Effect on Turnout.” Journal of Politics 80(3): 1045-51.

Grzymala-Busse, Anna. 2017a. "Global Populisms and their Impact." Slavic Review 76: S1-S8.

2017b. "Populism and the Erosion of Democracy in Poland and Hungary." Workshop on Global Populisms as a Threat to Democracy, Stanford University, November 3-4, 2017. https://fsi-live.s3.us-west-1.amazonaws.com/ s3fs-public/grzymala-busse_memo_1_0.pdf.

Haney-López, Ian. 2014. Dog Whistle Politics: How Coded Racial Appeals Have Reinvented Racism and Wrecked the Middle Class. New York: Oxford University Press.

Hassell, Hans J. G. 2017. The Party's Primary: Control of Congressional Nominations. New York: Cambridge University Press.

Hawkins, Kirk A. 2009. "Is Chávez Populist? Measuring Populist Discourse in Comparative Perspective." Comparative Political Studies 42: 1040-67.

Hawkins, Kirk A. and Cristóbal Rovira Kaltwasser. 2017. "The Ideational Approach to Populism." Latin American Research Review 52(4): 513-28. 
2018. "Measuring Populist Discourse in the United States and Beyond." Nature Human Behavior 2: 241-42.

Hawkins, Kirk A. and Levente Littvay. 2019. Contemporary US Populism in Comparative Perspective. Elements in American Politics. Cambridge: Cambridge University Press.

Hawkins, Kirk A., Scott Riding, and Cass Mudde. 2012. "Measuring Populist Attitudes." Working Paper Series on Political Concepts. ECPR Committee on Concepts and Methods, International Political Science Association, January.

Hertzke, Allen. 1993. Echoes of Discontent: Jesse Jackson, Pat Robertson, and the Resurgence of Populism. Washington, DC: CQ Press.

Hetherington, Marc J. and Jonathan D. Weiler. 2009. Authoritarianism and Polarization in American Politics. New York: Cambridge University Press.

Hibbing, John R. and Elizabeth Theiss-Morse. 1995. Congress and Public Enemy: Public Attitudes toward American Political Institutions. New York: Cambridge University Press.

2002. Stealth Democracy: Americans' Beliefs about How Government Should Work. New York: Cambridge University Press.

Hicks, William D., Seth C. McKee, Mitchell D. Sellers, and Daniel A. Smith. 2016. "A Principle or a Strategy? Voter Identification Laws and Partisan Competition in the American States." Political Research Quarterly 68: 18-33.

Hindman, Matthew. 2005. "The Real Lessons of Howard Dean: Reflections of the First Digital Campaign." Perspectives on Politics 3: 121-28.

Highton, Benjamin. 2017. "Voter Identification Laws and Turnout in the United States." Annual Review of Political Science 20:149-67.

Hofstadter, Richard. 1955. The Age of Reform. New York: Vintage Books.

Houle, Christian and Paul Kenny. 2018. "The Political and Economic Consequences of Populist Rule in Latin America." Government and Opposition 53: 256-87.

Howell, William G. 2003. Power without Persuasion: The Politics of Direct Presidential Action. Princeton, NJ: Princeton University Press.

Huber, Robert A. and Christian H. Schimpf. 2016. "Friend or Foe? Testing the Influence of Populism on Democratic Quality in Latin America." Political Studies 64: 872-89.

Huckfeldt, Robert and Carol Weitzel Kohfield. 1989. Race and the Decline of Class in American Politics. Chicago: University of Illinois Press.

Ignazi, Piero. 2003. Extreme Right Parties in Western Europe. New York: Oxford University Press.

Issacharoff, Samuel, Pamela S. Karlan, and Richard H. Pildes. 2012. The Law of Democracy: Legal Structure of the Political Process, 4th edition. New York: Foundation Press.

Judis, John B. 2016. The Populist Explosion: How the Great Recession Transformed American and European Politics. New York: Columbia Global Reports.

Kaltwasser, Cristóbal Rovira. 2014. "The Responses of Populism to Dahl's Democratic Dilemmas." Political Studies 62: 470-87. 2015. "Explaining the Emergence of Populism in Europe and the Americas." In The Promise and Perils of Populism: Global Perspectives, ed. Carlos de la Torre, 189-227. Lexington: University of Kentucky Press.

Kaltwasser, Cristóbal Rovira, Paul Taggart, Paulina Ochoa Espejo, and Pierre Ostiguy. 2017. "Populism: An Overview of the Concept and the State of the Art." In The Oxford Handbook of Populism, 1-26. New York: Oxford University Press.

Kammen, Michael. 1987. A Machine that Would Go of Itself: The Constitution in American Culture. New York: Alfred A. Knopf.

Kazin, Michael, 1995. The Populist Persuasion: An American History. Ithaca: Cornell University Press.

Kenny, Paul D. 2017. Populism and Patronage: Why Populists Win Elections in India, Asia, and Beyond. Oxford: Oxford University Press.

. 2019. “'The Enemy of the People': Populists and Press Freedom.” Political Research Quarterly. https:// doi.org/10.1177/1065912918824038.

Kinder, Donald R. and Cindy D. Kam. 2009. Us Against Them: Ethnocentric Foundations of American Opinion. Chicago: University of Chicago Press.

King, Desmond, Robert C. Lieberman, Gretchen Ritter, and Laurence Whitehead, eds. 2009. Democratization in America. Baltimore: Johns Hopkins University Press.

Kruse, Kevin. 2005. White Flight: Atlanta and the Making of Modern Conservatism. Princeton, NJ: Princeton University Press.

Kuo, Didi. 2018. "The Paradox of Party Polarization.” The American Interest, May 27. https://www.the-americaninterest.com/2018/03/27/paradox-party-polarization/.

La Raja, Raymond J. 2008. Small Change: Money, Political Parties, and Campaign Finance Reform. Ann Arbor: University of Michigan Press.

Lassiter, Matthew D. 2006. The Silent Majority: Suburban Politics in the Sunbelt South. Princeton, NJ: Princeton University Press.

Lee, Frances E. 2009. Beyond Ideology: Politics, Principles, and Partisanship in the US Senate. Chicago: University of Chicago Press.

Levitsky, Steven. 2010. Competitive Authoritarianism: Hybrid Regimes after the Cold War. New York: Cambridge University Press.

Levitsky, Steven and Daniel Ziblatt. 2018. How Democracies Die. New York: Crown. 
Lewis-Beck, Michael S. and Peverill Squire. 1995. "The Politics of Institutional Choice: Presidential Ballot Access for Third Parties in the United States." British Journal of Political Science 25: 419-27.

Light, Paul. 1999. The President's Agenda: Domestic Policy Choices from Kennedy to Clinton. Baltimore: Johns Hopkins University Press.

Lowndes, Joseph. 2008. From the New Deal to the New Right: Race and the Southern Origins of Modern Conservatism. New Haven: Yale University Press. 2017. "Populism in the United States." In The Oxford Handbook of Populism, eds. Cristóbal Rovira Kaltwasser, Paul Taggart, Paulina Ochoa Espejo and Pierre Ostiguy, 232-47. New York: Oxford University Press.

Lutz, Donald S. 1994. "Toward a Theory of Constitutional Amendment." American Political Science Review 88(2): 355-70.

Lynch, Marc. 2011. "After Egypt: The Limits and Promise of Online Challenges to the Authoritarian Arab State." Perspectives on Politics 9(2): 301-10.

Mair, Peter. 2013. Ruling the Void: The Hollowing of Western Democracy. London: Verso.

Manning, Jennifer E. 2019. "Membership of the 116th Congress: A Profile," Congressional Research Service Report, March 7. https://crsreports.congress.gov/product/pdf/R/R45583.

Mason, Lilliana. 2018. Uncivil Agreement: How Politics Became Our Identity. Chicago: University of Chicago Press.

McCarty, Nolan. 2019. "Polarization and the Changing American Constitutional System." In Can America Govern Itself? eds. Frances E. Lee and Nolan McCarty, 301-28. New York: Cambridge University Press.

McClosky, Herbert. 1964. "Consensus and Ideology in American Politics." American Political Science Review 58: 361-82.

Mendelberg, Tali. 2001. The Race Card: Campaign Strategy, Implicit Messages, and the Norm of Equality. Princeton, NJ: Princeton University Press.

Mény, Yves and Yves Surel, eds. 2002. Democracies and the Populist Challenge. New York: Palgrave, 2002.

Mickey, Robert. 2015. Paths Out of Dixie: The Democratization of Authoritarian Enclaves in America's Deep South. Princeton: Princeton University Press.

Mickey, Robert, Steven Levitsky, and Lucan Ahmad Way. 2017. "Is America Still Safe for Democracy?" Foreign Affairs, May/June.

Miller, Michael, David Szakonyi, and Lee Morgenbesser. 2018. "Expert Survey on American Democracy: MayJune 2018." Authoritarian Warning Survey. https:// www.authwarningsurvey.com/single-post/2018/07/ 06/Expert-Survey-on-American-Democracy-MayJune-2018.
Moffitt, Benjamin. 2016. The Global Rise of Populism: Performance, Political Style, and Representation Stanford, CA: Stanford University Press.

Mudde, Cas, 2004. "The Populist Zeitgeist." Government and Opposition 39(4): 541-63.

Mudde, Cas and Cristóbal Rovira Kaltwasser 2017. Populism: A Very Short Introduction. New York: Oxford University Press.

Müller, Jan-Werner. 2016. What Is Populism? Philadelphia: University of Pennsylvania Press.

Norris, Pippa. 2005. Radical Right: Voters and Parties in the Electoral Market. New York: Cambridge University Press.

Oliver, J. Eric and Wendy M. Rahn. 2016. "Rise of the Trumpenvolk: Populism in the 2016 Election." Annals of the American Academy of Political and Social Science 667: 189-206.

Pew Research Center. 2016. On Views of Race and Inequality: Blacks and Whites Are Worlds Apart, June 27. http://www.pewsocialtrends.org/2016/06/27/onviews-of-race-and-inequality-blacks-and-whites-areworlds-apart/.

Prothro, James W. and Charles M. Grigg.1960. "Fundamental Principles of Democracy: Bases of Agreement and Disagreement." Journal of Politics 22(2): 276-94.

Rabushka, Alvin and Kenneth A. Shepsle. 1972. Politics in Plural Societies. Columbus: Charles E. Merrill.

Rahn, Wendy M. and Howard Lavine. 2018. "Representation Gaps and Recent Presidential Elections," May 4. Institute for Governmental Studies. Berkeley: University of California.

Rauch, Jonathan and Raymond J. La Raja. 2017. ReEngineering Politicians: How Activist Groups Choose Our Candidates_Long before We Vote, December 7. Washington, DC: Brookings Institution.

Roberts, Kenneth M. 1995. "Neoliberalism and the Transformation of Populism in the Peruvian Case." World Politics 48: 82-116.

— 2007. "Latin America's Populist Revival." SAIS Review of International Affairs 27(1): 3-15. . 2017. "Populism and Political Parties." In The Oxford Handbook of Populism, eds. Cristóbal Rovira Kaltwasser, Paul Taggart, Paulina Ochoa Espejo, and Pierre Ostiguy, 298-304. New York: Oxford University Press.

Robertson, David Brian. 2011. Federalism and the Making of America. New York: Routledge.

Rosenbluth, Frances McCall and Ian Shapiro. 2018. Responsible Parties: Saving Democracy from Itself. New Haven: Yale University Press.

Rosenstone, Steven J., Roy L. Behr, and Edward H. Lazarus. 1984. Third-Parties in America, 2nd edition. Princeton, NJ: Princeton University Press.

Rudalevige, Andrew. 2006. The New Imperial Presidency: Renewing Presidential Power after Watergate. Ann Arbor: University of Michigan Press. 
Ruijgrok, Kris. 2017. "From the Web to the Streets: Internet and Protests under Authoritarian Regimes." Democratization 24(3): 498-520.

Rummens, Stefan. 2017. "Populism as a Threat to Liberal Democracy," In The Oxford Handbook of Populism, eds. Cristóbal Rovira Kaltwasser, Paul Taggart, Paulina Ochoa Espejo, and Pierre Ostiguy, 554-70. New York: Oxford University Press.

Ruth, Saskia P. 2018. "Populism and the Erosion of Horizontal Accountability in Latin America." Political Studies 66: 356-75.

Ruth-Lovell, Saskia P., David Doyle, and Kirk A. Hawkins. 2019. "Consequences of Populism Memo for The Guardian's New Populism Project.” Team Populism, March 6, https://populism.byu.edu/App_Data/Publications/TP_Consequences_Memo.pdf.

Rydgren, Jens. 2005. "Is Extreme Right-Wing Populism Contagious? Explaining the Emergence of a New Party Family," European Journal of Political Research 44: 41337.

Sanders, Elizabeth. 1999. Roots of Reform: Farmers, Workers, and the American State, 1877-1917. Chicago: University of Chicago Press.

Sandri, Giulia, Antonella Seddone, and Fulvio Venturino, eds. 2015. Party Primaries in Comparative Perspective. Burlington, VT: Ashgate.

Schlozman, Daniel and Sam Rosenfeld. 2019. "The Hollow Parties." In Can America Govern Itself? eds. Frances E. Lee and Nolan McCarty, 120-51. New York: Cambridge University Press.

Schmidt, Gregory D. 1996. "Fujimori's 1990 Upset Victory in Peru: Electoral Rules, Contingencies, and Adaptive Strategies." Comparative Politics 28: 321-54.

Shugart, Matthew Soberg and John M. Carey. 1992. Presidents and Assemblies. New York: Cambridge University Press.

Sides, John, Michael Tesler, and Lynn Vavreck. 2018. Identity Crisis: The 2016 Presidential Campaign and the Battle for the Meaning of America. Princeton, NJ: Princeton University Press.

Skocpol, Theda and Vanessa Williamson. 2016. The Tea Party and the Remaking of Republican Conservatism. New York: Oxford University Press.
Sullivan, John L., James Piereson, and George E. Marcus. 1982. Political Tolerance and American Democracy. Chicago: University of Chicago Press

Taggart, Paul A. 2002. "Populism and the Pathology of Representative Politics." In Democracies and the Populist Challenge, eds. Yves Mény and Yves Surel, 62-80. New York: Palgrave.

Tamas, Bernard. 2018. The Demise and Rebirth of American Third Parties: Poised for Political Revival? New York: Routledge.

Tamas, Bernard and Matthew Dean Hindman. 2014. "Ballot Access Laws and the Decline of American Third-Parties." Election Law Journal 13(2): 260-76.

Tarrow, Sidney. 1996. "States and Opportunities: The Political Structuring of Social Movements." In Comparative Perspectives on Social Movements: Political Opportunities, Mobilizing Structures, and Cultural Framings, eds. Doug McAdam, John D. McCarthy and Mayer N. Zald, 41-61. New York: Cambridge University Press.

Tesler, Michael. 2016. Post-Racial or Most-Racial: Race and Politics in the Obama Era. Chicago: University of Chicago Press.

Tichenor, Daniel J. 1994. "The Politics of Immigration Reform in the United States, 1981-1990." Polity 26: 333-62.

Veuglelers, John and André Magnan. 2005. "Conditions of Far-Right Strength in Contemporary Western Europe: An Application of Kitschelt's Theory." European Journal of Political Research 44: 837-60.

Ware, Alan. 2002. "The United States: Populism as Political Strategy." In Democracies and the Populist Challenge, eds. Yves Mény and Yves Surel, 101-19. New York: Palgrave.

Weyland, Kurt. 2013. "The Threat from the Populist Left.” Journal of Democracy 24: 18-32.

Weyland, Kurt and Raúl L. Madrid, eds. 2019. Trump's Populism: The Mobilization of Nationalist Cleavages and the Future of US Democracy. New York: Cambridge University Press.

Wilcox, Clyde. 2008. "Internet Fundraising in 2008: A New Model." The Forum 6: Art. 6.

Zakaria, Fareed. 1997. "The Rise of Illiberal Democracy." Foreign Affairs 76 (Nov.-Dec.): 22-43. 